\title{
Lexical material of regional content in the process of implementing the communicative approach in teaching English to students of non- linguistic specialties
}

\author{
Vladimir B. Pomelov - Rezeda R. Khairutdinova - Nina I. Kryukova
}

DOI: 10.18355/XL.2018.11.01.13

\begin{abstract}
The purpose of this article is to study the positive, practical experience of using didactic (lexical) material of regional content in the process of implementing the communicative approach in teaching English to students of non-linguistic specialties. The leading method in the study is the pedagogical experiment (ascertaining, forming and control stages of the experiment), as well as the method of expert evaluations, statistical processing of quantitative research results, observation, questioning, modeling of situations, dramatization. The specificity of the authors' method of applying the communicative approach, implemented in the form of a dialogue, using the vocabulary of a regional orientation, allows to increase the effectiveness of training sessions, raise the level of interest in learning English. The authors developed the content of training courses with regional orientation. The study proved the effectiveness of introducing lexical material of regional orientation.
\end{abstract}

Key words: communicative approach, regional content of lexical material, the English language, teaching methods

\section{Introduction}

\subsection{The urgency of the problem}

The current period of the development of Russian society is characterized, in particular, by the fact that nowadays, as never before, the youth faces a problem of receiving a high-quality education. The well-known definition of science as an engine of social progress can be supplemented by the definition of education as a driving force for the development of the personality of each individual member of the society. In the current system of values, education takes one of the leading places, along with such values like health, family, career. From learning for life period to lifelong learning, this is the basic tenet of the education in the first quarter of the 21 st century, and education itself increasingly becomes an inseparable and prestigious component of the image of a modern successful person.

An important component of modern quality education is the good teaching of foreign languages. The educated Russian intelligentsia of the pre-Soviet period, who often went abroad, and often received higher education in foreign universities, considered knowledge of one or even two foreign languages, and from A to Z, something natural, self-evident. The pedagogical press of the second half of the XIX century. seriously discussed the possibility of switching the gymnasiums to teaching all academic disciplines in a foreign language, and such a proposal didn't draw any objections among prominent Russian teachers of that time (Pomelova, 2010). The notorious "Iron Curtain," fallen over Russia after the Great October Socialist Revolution of 1917, had a particularly significant impact on the study of this particular subject. Teachers of foreign languages actually lost the opportunity to travel abroad, communicate with colleagues and learn methodical innovations from foreign colleagues. The teacher of the Tsar's gymnasium, who really knew a foreign language, was replaced by a teacher who knew the language to a greater or lesser degree, that is, who studied phonetics, syntactic structure, grammar, and, in part, vocabulary (Passov, 1989). Of course, such a teacher focused in his work on phonetics, translating texts, 
grammatical exercises to the detriment of developing oral speech, in which he, as a rule, had poor skills (Pomelova, 2009).

In the previous historical period, their study at school and university was not given such significant importance, as it is nowadays. This was mainly due to the authorities' unwillingness to promote the USSR citizens' interest to the life abroad, especially in English-speaking, capitalist countries. Therefore, the content of school and university textbooks on foreign languages provided for a greater degree the mastery of grammatical, phonetic and syntactic structures, which sometimes went against learning vocabulary treasures of the language and developing conversational skills, which, however, were practically nowhere to apply.

This approach, called "traditional," or "grammatical," is widely used to this day in educational institutions of all levels (Kasimova, 2009). Its foundation is studying grammatical rules, their application in sentences (syntactic constructions) with a subsequent drill in exercises. The leading method here is the lexical-translation method (Palmer, 1960). This leads to the student's, even speaking a foreign language, continuing to think in his native language (Millrud, 2000).

The traditional way allows you to learn grammar well, learn to read, write, and have a rich lexical stock. In Soviet teaching aids in English, Russian realities prevailed. For example, the "cross-cutting theme" in school textbooks from the 5th to the 10th grades in English was a notorious family of some "Muscovites, the Stogovs" (Mirolubov, 1981). And at the same time, there were no texts about the life of the British and Americans.

However, comprehensive strengthening of intergovernmental relations of the Russian Federation with other countries, which has a positive effect on the development of economic, cultural, sporting and other relationships at the level of organizations and institutions, as well as establishing friendly relations among ordinary citizens of different countries, gives grounds to assert that the role and significance of a foreign language as a means of communication in future will only increase, and this, in turn, increases the importance of the relevant academic subject at school and university (Pavlovskaya, Bashmakova, 2007).

Modern trends in social development require a completely different approach to the methodology of the foreign language teacher's work. In recent decades, Russian methodologists have put forward an active method of teaching foreign languages (Passov, 1991). This approach could be called communicative, that is, aimed at interacting with native speakers, real professional and friendly communication with them, successful learning the foreign social and linguistic environment and the subsequent comfortable and useful stay in it. Its most significant features are the practical orientation of language teaching at school and university; the communicative and verbal basis of the language learning process; complex organization of language material; differentiated approach to training; all-around intensification of the educational process.

The following principles are put forward as the main ones: verbal and cogitative activity, individualization, functionality, situational, "novelty" (Shamov, 2008). The political basis for this approach was the transition of Russian education system to a two-level (Bologna) system of training highly qualified professionals. There are problems of a content nature when implementing the objectives of the Bologna Agreement. For example, there arises a question of how it is possible to take into account the diverse needs of students of different specialties and different areas of the bachelor's degree in the conditions when existing directives imply all students' mastering the same training material. However, it's good that the number of hours for teaching a foreign language remains the same. Moreover, training at master courses also involves the academic discipline "Foreign Language in Professional Activities."

XLinguae, Volume 11 Issue 1, January 2018, ISSN 1337-8384, eISSN 2453-711X 
The analysis the English language teachers' experience made it possible to single out the following contradictions of the modern practice: - between growing needs of society in professionals who are fluent in foreign languages in actual interethnic communication, on the one hand, and a persisting emphasis in teaching on the traditional grammatical approach and the lexical-translation method, which leads to an insufficient practical knowledge of a foreign language, on the other hand; - the desire of foreign language teachers to expand the topics of studies, on the one hand, and insufficient methodological equipment of the educational process.

As a result, the effectiveness of the learning process, as we assume, largely depends on the effective use of the communicative approach and introduction of a new, interesting for the students, lexical content with a regional focus.

\subsection{Goals and objectives of the study}

The aim of the study is to examine the positive, practical experience of using didactic (lexical) material of regional content in the process of implementing the communicative approach in teaching English to students of non-linguistic specialties. The following objectives of the study were identified as the main ones: to study the possibility of using the lexical material of regional content in the process of implementing the communicative approach in the process of teaching English to students non-linguistic specialties; to include tasks on the regional theme in English in the interactive training system.

\subsection{The degree of the problem development}

In the scientific and methodical literature, there are a lot of materials concerning the problem of using a communicative approach. However, almost all of these materials concern school education. There are not enough methodological toolkits on the level of training students of non-linguistic specialties. In addition, the problem of using the vocabulary of regional orientation is poorly developed in the modern methodology of teaching foreign languages.

\subsection{Theoretical and practical contribution of the materials of the article}

It is proposed to use the communicative approach as a method for interactive teaching English to students of non-linguistic specialties of higher education institutions using the vocabulary of regional orientation. In teaching English, the use of speech activities such as speaking and listening is suggested, since the main goal of educating migrant children is to teach them to speak and communicate in English. The work with students included situationally conditioned dialogues taking into account the level of English language proficiency.

\section{Literature Review}

\subsection{The analysis of Russian scientific and educational literature}

The problem of finding the most effective means of teaching foreign languages is one of the most important in modern Russian methodological science. Russian authors constantly address it. Leading scientists study the methodological foundations for teaching foreign languages in connection with various more specific problems, in particular, the need to improve educational literature, which clearly lacks materials aimed at developing communicative skills and skills in oral speech (Galskova, Gez, 2006). Studying a foreign language is fairly considered by leading Russian philologists as an important pedagogical tool for forming the personality. Thus, based on an extensive material the researcher P.I. Sysoev (2013) has established leading information and communication technologies in linguistic education. V.A. Valeev, L.A. Valeeva, A.F. Sirazeeva (2015) conducted a study of students' speech activity in the process of mastering a foreign language. Scientists-linguists from Kirov L.N. 
Ponomarenko et al. (2017) turned to the problem of forming discourse competence of students of pedagogical specialties while studying foreign languages in the process of intercultural dialogue (dialogue of cultures). The famous Russian researcher V.V. Safonova (1996) approaches the problem of studying foreign languages from the perspective of a dialogue between cultures and civilizations. S.Y. Zalutskaya, A.I. Oschepkova and N.I. Nikonova (2017) devoted their research to the problem of training Masters of Humanities in cross-cultural communication. Russian scientists turn to the experience of foreign colleagues, in particular, German ones, in an effort to identify modern methodological approaches to studying English at universities (Martynova et al., 2015).

In addition to general theoretical studies related to the study of a communicative approach itself, the authors study to some extent more specific aspects of this problem, namely, the use of certain methods and techniques in a communicative approach designed to make the learning process more interesting and meaningful, and, which, perhaps, is the most important, more attractive for students. Of course, these are, first of all, works describing certain game techniques. L.A. Kaprimova (2009) was engaged in developing theoretical bases for teaching English on a game basis. T.M. Mikhaylenko (2011) substantiated the game technology as a form of educational technologies. M.S. Nazarova and E.N. Galiullina (2016) elaborated this idea and put forward a method of teaching English based on a game basis.

A.A. Gorynina and N.G. Sosnina (2015) put forward the game technology as a means of activating communicative skills of students of non-linguistic specialties. O.V. Sumtsova, Y.P. Agel and A.S. Buyankina (2016) propose a roleplay based on webquests as an effective form of work with students. S.L. Khabirova and M.L. Ruslanova 2015) developed the technology of dramatization and justified it as a creative method of teaching English.

\subsection{The analysis of foreign studies}

The analysis of foreign sources shows that the problem of using the communicative approach, and in particular the search for active ways of teaching foreign languages at university, is paid considerable attention, and in different aspects. So, the scientists S. Somsai and C. Interaprasert (2011) devoted their research to the effectiveness of oral dialogue communication (face-to-face communication) in the course of teaching English to Thai students. The researcher Z. Bojović (2016) developed a methodology for teaching the German language to migrant students in order to create communicative competencies at a level that allows them to understand German speakers at the level of independent comprehension. In the classroom, students use lexical units in quasi-real life situations, and they tend to express their thoughts in German. During classes, students and teachers tend to do without their native language, especially since it, or rather - they are different. Explanations are given through known phrases and lexical constructions; they also use facial expressions, gestures, audio recordings, visual material. Z. Bojović, L. Palunović and L. Tica (2015) developed a methodology for forming communicative skills of students future engineers.

Scientist C. Convertino (2016) proposes to use the method of dialogue teaching for language teachers in the conditions of multicultural education. Such training is built on the interaction of participants in the process of communicating, understanding and achieving a common communicative goal, trying to explain and express things in various ways, expanding the competence of one participant of communication through communication with other participants. The researcher S. Maherzi (2011) investigated the influence of the classroom atmosphere on the motivation for learning English. C.M. Greenfader and L. Brauillette (2013) found the positive impact of dramatization and motor activity on the formation of language skills in the process of learning

XLinguae, Volume 11 Issue 1, January 2018, ISSN 1337-8384, eISSN 2453-711X 
English. L.F.G. Rodriguez (2015) identified opportunities to overcome such a negative trend in today's multicultural society as a loss of cultural identity on the example of teaching English to students at the University of Bogota (Colombia); as an instrument of influence, he suggests a method of immersion in the local, national culture.

In other words, relevant topics with the appropriate regional vocabulary are necessary. G. Marcelio-Barés, E. Liurda (2013) on the basis of the University of Catalonia (Spain) conducted a study in which students' language competencies were analyzed; the study compares what students have received and knew in terms of language training, on the one hand, and how this knowledge meets the expectations of the business in which they plan to work.

C.M. Nkwetisama (2013), using the example of students in Cameroon, points in his study to the need of strengthening the role of fiction in teaching English; for the learning process to be more interesting, one should use such methods as dramatization, games.

Thus, the problem of using the communicative approach in teaching foreign languages is extremely relevant in the modern educational practice of higher education. However, the use of regional lexical content was not studied in the works of foreign authors, which emphasizes the relevance of our study.

\section{Materials and Methods}

\subsection{Theoretical and empirical methods}

To test the hypothesis, a set of various methods complementary to each other was used:

- theoretical - the analysis of the works of teachers and psychologists on the problem of research; the analysis of methodological and educational literature; the theoretical analysis of the main provisions of the proposed methodology, on the basis of which the hypothesis of the research was put forward; the theoretical justification of the system of teaching English to students of non-linguistic specialties;

- empirical - inclusive observation, the ascertaining and forming pedagogical experiment, questioning, testing, the analysis of the results of experimental work.

\subsection{The base of the research}

The study was conducted on the base of the Pedagogical Faculty of the Federal State Educational Establishment of Higher Education "Vyatka State University of Humanities." One hundred and fifty students of the specialty "Pedagogy and methodology of primary education" with an additional specialty "English language" participated in the experiment.

\subsection{Stages of the research}

The study was conducted in three stages:

The first stage determined the general direction of the scientific work, analyzed the scientific and methodological literature, formulated the goal and main tasks of the study, studied the state of the problem, generalized the principles of the communicative approach in teaching, summarized the teachers' opinions, conditions for organizing a pedagogical experiment.

Selection of research methods was carried out, an experimental site was established on the base of the above-mentioned educational institution, monitoring of the educational process and the character of the students' language adaptation was carried out; forms of the teacher's work with students in English classes were studied; students' questioning was conducted; the level of students' English language proficiency was tested; the research topic on the initial stage of the ascertaining stage of the experiment was validated. 
The second stage determined the content of the teacher's work; organized the ascertaining stage of the pedagogical experiment, which included observation, questioning, ascertaining the initial state of using the communicative approach in teaching English, reviewed and corrected the theoretical conception of the study, conducted training according to the developed methodology.

The third stage carried out the forming stage of the pedagogical experiment (actual experimenting), which included introducing lexical material of regional content in the process of implementing the communicative approach in teaching English. The analysis, generalization, and systematization of the received data were carried out; the research was documented; the research topic was tested in the publications and the author's talks at scientific conferences.

\subsection{Evaluation criteria}

Diagnosis of the level of the students' language competence formation was conducted in accordance with the European system of levels of foreign languages proficiency. Characteristics of competences are found in the Council of Europe's document entitled "Common European Framework of Reference: Learning, Teaching, Assessment." The Russian translation and publication were carried out by the Moscow State Linguistic University (Iriskhanova, 2003). In accordance with this document, the levels of knowledge of a foreign language are divided into three scales: A (basic user), B (independent user), C (proficient user). Each scale has a division into two levels: A1 - breakthrough and A2 - way stage levels; B1 - threshold and B2 - vantage levels, $\mathrm{C} 1$ - effective operational proficiency and C2 - mastery levels We set the task of students' achieving levels B1 and B2.

\section{Results}

\section{The ascertaining stage of the experiment}

To carry out the experiment, two groups of students were selected annually, during 2008-2009: the experimental group and the control group, 17-18 students each. Students of both groups were tested for the level of communication skills according to two criteria - listening and speaking. Students were given the task to compose a dialogue in English of 5-6 phrases on the topic "Acquaintance" (listening), to produce the dialogue with a friend (speaking).

More clearly, the results of the ascertaining stage of the experiment are presented in the tables below. In short, here and below, the data for 2010 are shown.

Table 1. The results of the control group on the ascertaining stage of the experiment

\begin{tabular}{|l|l|l|l|l|}
\hline $\begin{array}{l}\text { Language components / Proficiency } \\
\text { level }(\%)\end{array}$ & A1 & A2 & B1 & B2 \\
\hline Speech skills and & 33 & 67 & & \\
\hline $\begin{array}{l}\text { Understanding the topic an } \\
\text { situation of communication }\end{array}$ & 71 & 29 & & \\
\hline Ability to keep the dialogue & 19 & 71 & 10 & \\
\hline Using prepared model and extra & 25 & 63 & 12 & \\
\hline $\begin{array}{l}\text { Activation speech and } \\
\text { linguistic means }\end{array}$ & & 41 & & \\
\hline
\end{tabular}

The students of the control group are at the threshold level of the knowledge of Russian. They understand certain familiar words and simple phrases in a slow and 
clearly sounding speech in situations of everyday communication when they talk about their family and the nearest environment (Table 1).

Table 2. The results of the experimental group on the ascertaining stage of the experiment

\begin{tabular}{|l|l|l|l|l|}
\hline Language components / Proficiency level (\%) & A1 & A2 & B1 & B2 \\
\hline Speech skills & 64 & 36 & & \\
\hline Understanding the topic and situation of communication & 31 & 59 & & \\
\hline Ability to keep the dialogue & 72 & 28 & & \\
\hline Using prepared model & 24 & 67 & 9 & \\
\hline Activation speech and extra linguistic means & 31 & 67 & 2 & \\
\hline
\end{tabular}

The students of the experimental group showed an initial level of the knowledge of the Russian language. They were able to use simple phrases and sentences, keep dialogue within one phrase (Table 2).

The ascertaining stage of the experiment showed that the students of the control and experimental groups have a low level of the communicative competences formation. They can be attributed to groups A1 and A2. The data of the experiment revealed that the most typical difficulties in mastering the English language by students of nonlinguistic specialties are the following: the phonetic system of the Russian language; the category of gender and case; the category animate / inanimate; the order of words in a sentence.

\section{The forming stage of the experiment}

The goal of the forming stage of the experiment was to teach students to understand live Russian speech and interpret the speech behavior of the communication partner correctly, to ensure that they can communicate in English on certain topics.

To achieve the goal of the forming stage of the experiment, first of all, we turned to the analysis of the English language teachers' educational activity, which made it possible to identify the basic principles of the communicative approach in teaching.

1. The principle of speech orientation. The speech orientation of the educational process is in pursuing a practical speech goal and also that the practical language use is the way to this goal. Speech orientation involves the use of exercises in pronunciation and speaking. The principle of speech orientation involves the use of communicatively valuable speech material.

In the interests of the study, the vocabulary of regional orientation was used in the content of the lessons. The use of each phrase should be justified by the communicative value for the intended sphere of communication (situation) and for the given category of students.

2. The principle of individualization with the leading role of the personal aspect. Individualization takes into account students' interests and their properties: abilities, ability to carry out speech and educational activities.

3. The principle of novelty. The process of communication is characterized by a constant change in the topic of conversation. Novelty provides flexibility of speech skills. The implementation of the principle of novelty was carried out through a change in the forms of work.

4. The principle of collective interaction allows students to communicate actively with each other and becomes a condition for everyone's success.

5. The principle of modeling is to use such non-traditional methods as dramatization, games, etc. Based on these principles of the communicative approach, a program of further actions was drawn up. 
The English teacher's work on the use of lexical material of regional content in the process of implementing the communicative approach in teaching English to students of non-linguistic specialties involved the following elements.

In practical work with students, the teacher strives to ensure that at the foreign language lessons (English language) they have a possibility to communicate in the foreign language, to acquire communication skills, to receive interesting information about the target-language country, and so on. The focus was on group learning.

An important task for the teacher and students was to learn how to work together, to move away from individualized learning, which, according to the leading methodologists, makes it possible to master oral dialogical speech more successfully.

Each student learned to listen to his fellow-students, to conduct talks and discussions in the group, to work with other members of the group. Traditional exercises and tasks in teaching foreign languages were used according to the communicative technique: projects, communication games, communicative exercises, staging, dramatization.

The first step in using the communicative technique is to memorize words and expressions, and only then to impose the existing knowledge on their grammatical basis. In the process of learning, language skills develop. Students learn to speak easily and freely

During classes students and teachers do not speak their native language. All explanations were done with the help of already familiar phrases and lexical constructions. Mimicry, gestures, audio-recordings, visual material: videos, pictures, photos, were used in the explanation. An important point in the process of learning was students' immersing in the culture, geography, history of the target-language country; they read this country's press, watch TV shows and listen to music in a foreign language.

The next important step in implementing the communicative approach was the work of students in pairs. The teacher created all kinds of situations so that students could try themselves in real communication. This kind of work allows students to correct each other independently, to find mistakes in their speech and in the speech of their partner. Discussing various topics and questions in groups, they can help their fellowstudents express the idea correctly, construct a sentence to make it clear.

An integral part of communicative learning is role-playing and dramatization. They are especially effective in the first stage of language learning. All kinds of interesting situations are played out between students. Various performances, short plays, and fairy tales are staged; everyday life situations are played out. The main task of these games is to promote the development of oral speech. Plots can be very simple - a visit to a store, an excursion, getting acquainted. Participants should get out of any difficult situation, using only the vocabulary of a foreign language.

On the next stage of studying a foreign language, dramatization is replaced by a more complicated kind of game, for example, a problem situation. The problem situation may be the following: you are lost in an unfamiliar city and are trying to figure out how to get to the hotel, the address of which you have forgotten or lost. Such training allows students to widen their horizons of the target-language country and also to check the general level of knowledge, wit, erudition, logic. An important point here is competition itself, the desire to win. This makes participants think faster, and to think in a foreign language.

Communicative methods also include discussion games. The essence of these games is to discuss and analyze current topics that are urgent for students. Each student expresses his views on this or that issue. The teacher directs the students, develops the topic, asks suggestive questions, expresses his/her opinion. Discussion topics are very diverse, from discussing favorite films and music to the problems of ecology and unemployment, attitudes toward marriage and divorce, etc. (Passes, 1991).

XLinguae, Volume 11 Issue 1, January 2018, ISSN 1337-8384, eISSN 2453-711X 
These discussions require a relaxed atmosphere and help students to communicate freely in a foreign language. Such simple communication removes psychological fear and tension; students gradually begin to express their thoughts clearly and correctly (Pavlovskaya, 2003). Students are very active and interested in playing drama games, such as "Britain's Wedding", "Travel Agency", "Alma Mater" ("Home University"), , "The House of my Dream", "Fashion Show", during discussing such topics as "To clone or not to clone?" ("Cloning: yes or no? "),"What is it like to be British? "("What is it to be British?").

The project "Press conference" I am a famous person" is always successful as well as many other forms of interactive work with students. In the course of preparing and implementing these activities, the teacher aims at ensuring that students receive an adequate understanding of the target-language countries, developing their communicative skills, deepening linguistic knowledge and expanding their capabilities in terms of implementing all the prospects laid down in the Bologna Declaration.

The twofold nature of the educational process encourages each teacher to build such classroom activities and guide the students' independent work, which would take into account the need to solve two types of interrelated tasks, namely, the tasks of training and the tasks of education. Although the first tasks, undoubtedly, prevail in their importance over the second in classes and students independent work, the teacher should always remember the educational aspect of training

Recently, when the role and importance of the regions in the socio-political life of the country have increased significantly, pedagogical science, and in particular teaching methods of individual academic discipline give special attention to the upbringing of the younger generation on the example of the famous countrymen's life and work, their deeds and achievements, on the example of significant historical events from the local (regional) history. In this regard, since the Soviet times "Foreign Language," as an academic subject in educational institutions of general, secondary and higher professional education, has traditionally been considered as a subject "responsible" for developing young people's internationalism.

But, as we know, the concept closest to internationalism is patriotism. That is why one of the tasks of the teacher, the teacher of a foreign language, is the task of cultivating love for their homeland, including the place where the person lives and works, to the so-called "minor Motherland" (we take this phrase "just in case" in quotation marks, because not all researchers consider it possible for such a division into a "minor" and "major" homeland).

The importance of solving this problem increases manyfold in the case when it comes to students - future teachers of primary classes, for whom English is the second specialty. This circumstance makes high demands, both for students and for the teacher of a foreign language. At the same time, it is known that none, even the best idea, can be learned by students in the event if the teacher is not able to establish contact with them.

It seems quite obvious that such a complex educational task - developing patriotism and forming communicative skills of the future teacher - cannot be solved by linguistic means themselves that is, exclusively in the process of mastering phonetics, grammar, vocabulary.

A sufficiently wide opportunity for developing patriotism and forming communicative skills in foreign language classes and in the process of independent work on this subject is opened by using a content component, namely, in the process of work with relevant texts. Therefore, particular attention was paid to the selection of content material in work with students. Let's show how we do this on the example of work with the text about our hometown of Kirov. Below is its content.

\section{My native town}


The region, we live in, the Kirov region is one of the largest in our country: its territory covers 120.7 thousand square kilometers, and its population amounts to 1.5 million people. The region borders the Perm and the Nizhni Novgorod regions, Komi, Tatarstan, Mari Al and Udmurt Republics.

The climate of our region is continental. That means that in winter we have strong frost and in summer the heat is quite usual. The Kirov region is very rich in water resources. There are a lot of rivers and lakes there. Among the rivers, the major ones are the Vyatka (the longest and the widest of them), the Lusa, the Vetluga, the Bolshaya Kokshaga, and the Kama (in its upper reaches). The Kirov region is rather rich in minerals, such as phosphorites, iron ores, peat, limestone, gypsum, schist, sand, waters rich in mineral salts, and mineral dye-stuffs.

The most important treasure of our region is timber. The main part of the region's territory is covered with forests. Their exploitation and timber-rafting are widelyspread, and the most developed branch of industry is the production of timber. A large number of Kirovites work as woodcutters and truck-drivers in this branch of industry. Kirov timber is sold abroad. Nowadays we face the problem of deforestation - an aftereffect of irresponsible forests' exploitation.

As distinguished we can name such towns of our region, as Vyatskie Polyany, KirovoChepetsk, Nolinsk, Kotelnich, Slobodskoi, and others. All of them are known for the famous people born there, and for their achievements; as well as for their industry and handicraft. For example, Nolinsk is the birthplace of the Communist Party leaders A. I. Rykov and V. M. Molotov, of the actor B. P. Chirkov and other outstanding people. This town is the center of the world-famous, hand-made lace.

In Kirovo-Chepetsk, one of Russia's largest chemical plants is situated. The hockeyteam of this town, "Olympia," gave the world of the sport such famous hockeyplayers, Olympic champions, as the forward A. Maltsev, the goalkeepers V. Myshkin and A. Trefilov, and others.

The Vyatka region is the birthplace of such famous people of our country as the composer P. I. Tchaikovsky; the painters I. I. Shishkin, A. A. Rylov, the brothers V. M., and A. M. Vasnetsov; the singer F. I. Shalyapin; the Russian national hero, the first woman-officer in the Russian army N.A. Durova (among whose offspring are the well-known circus actors - the Durovs' dynasty, and our contemporary, the cinema and theatre actor Lev Durov); the writers Alexander Green, A. A. Likhanov, and V. N. Krupin; the poet N. A. Zabolotsky (the author of the famous poem "Do Not Let the Soul Be Idle"); the opera conductor E. M. Kolobov; and many others.

The Vyatka citizens are proud of their war-heroes. During the years of the Great Patriotic War 1941 - 1945 more than two hundred soldiers and officers from our region were awarded the honorary title of the Hero of the Soviet Union. This figure ranks fifth among all the regions of our country and can rank first if we take into consideration the size of the population of the region. Among the most famous marshals-Kirovites, we can name I. S. Konev, L. A. Govorov, and K. A. Vershinin.

The first cosmonaut, born in our region, V. P. Savinykh, is the 50th cosmonaut of the Soviet Union and at the same time the 100th cosmonaut of the world. He accomplished three cosmic flights in 1981, 1985, and 1988. Viktor Petrovich Savinykh was born on the 7th of March 1940 in the village of Berezkiny, Orichi district, Kirov region. He graduated from Moscow Land-Surveying and Cartographic Institute, and presently he is its rector. He was awarded the title of the Hero of the Soviet Union twice (in 1981 and in 1985). He is the doctor of technical sciences, professor, honorary citizen of his native town and the region on the whole. The second cosmonaut born in our region is the Hero of the Soviet Union, A. A. Serebrov, born on February 15, 1944. His flights took place in 1982, 1983, 1989-1990, 1993-1994.

The Vyatka (Kirov) region is the birthplace of the well-known scientists: K.I. Schepin - the first Russian doctor of medicine; A.N. Bakulev - the famous heart surgeon, the

XLinguae, Volume 11 Issue 1, January 2018, ISSN 1337-8384, eISSN 2453-711X 
President of Medical Academy of Sciences; A. Z. Puni, V. S. Serebrennikov, E. A. Klimov, E. I. Monoszon, V. G. Razumovsky, L. A. Tsvetkov; and many others.

The town of Kirov was founded in 1374. It is one of the ancient Russian towns. Its first name was Khlynov, as it was founded on the banks of the small river Khlynovka. The town got name Vyatka at the end of the 18th century (in 1780) because at that time after the town had grown beyond its former boundaries, its main part started spreading along the river Vyatka. In 1934 our town was renamed Kirov, after the revolutionary leader, S. M. Kirov, who was born in Urzhum, not far from Vyatka.

During the tsarist times, the Vyatka region was the place of political exile. The tsars sent here outstanding political leaders, writers, and other representatives of culture who were in opposition to the ruling regime. Among them were the writers A. I. Hertzen (who was in exile here in 1835 - 1837), M. E. Saltykov-Schedrin (in $1848-$ 1855), V. G. Korolenko (in 1869 - 1870), the book publisher F. F. Pavlenkov (in 1869 - 1877), the revolutionaries F. E. Dzerzhinsky, N. E. Bauman, and others. Many of them left their mark on the town and made a contribution to its development. For example, A. I. Hertzen made great efforts to open the public library in Vyatka, which is now named after him and is one of the largest in Russia. Numerous pages of his memoirs The Past and the Thoughts Hertzen devoted to the Vyatka period of his life.

M. E. Saltykov-Schedrin perfected his skills of a satirist here, in Vyatka. In one of his best works, the Gybernian Essays, he described the customs of the so-called "noble society" of this town. V. G. Korolenko devoted his main work, The History of My Contemporary, to the Vyatka people. F. F. Pavlenkov opened a number of schools and published many books for children and adults during the period of exile.

Nowadays Kirov is a great center of industry and culture, with a total population of more than 500 thousand people. Its industry produces washing machines - automates "Vyatka - Alyonka," high-quality furniture, electric stoves, automobile tires, textiles, toys, skis, foodstuffs, and other goods.

There are many educational institutions in our town. Among them, we can name Medical Academy, Agricultural Academy, Vyatka State University. More than 20 thousand students take full-time and correspondence courses at its various departments.

The symbol of our town is a clay Dymkovo toy. (Dymkovo is a small village in our region famous for its handicraft - toys made of clay). The Dymkovo toys are often shown at different folk-art expositions and are displayed at famous museums and art galleries, for instance, at the State Russian Museum in St. Petersburg. Among the most skilled artists who are engaged in this craft, we can name L. S. Falaleeva, E.I. Koss-Denshina and O .I. Konovalova. Welcome to Kirov!

At first, the student was acquainted with the text and the essential vocabulary. Then the students worked on translating the text, studying the vocabulary, answering questions on the content of the text, composing dialogues and monologues based on the text, certainly expressing their own opinions about the city in which they live: about what they like and what they would like to change. This indicates that they are not indifferent to their city, their "minor homeland." The students composed dialogues in the name of one or another character from the history of our city, for example, the artist Vasnetsov or the cosmonaut Savinykh. The following forms of work were used: stories about themselves, a press conference, during which the "guest" answered "journalists'" questions. At the end of the topic, as usual, there was a project - a creative, independent students' performances. For a number of years, students have been carrying out with great interest the event "Travel Agency." Their task is to develop and submit a draft excursion around their favorite city, to interest "potential customers."

In the process of preparing for this event, although starting from the text available on this topic, students independently learn a lot about the sights and interesting places, 
people of their native city. This kind of activity is very interesting for nonresident students since almost all information for them is new and useful because they are now residents of our city. As a result, by voting students choose the best route around Kirov. In the conclusion of the work on the topic, a real city tour is organized, which, of course, causes a lot of positive emotions among students, promotes their closer relations, establishes better contacts in the group, and, of course, encourages students to learn their hometown better.

\section{The control stage of the experiment}

The purpose of this stage is to diagnose the formation of students' communicative competence. On the stage of the control experiment, the students of the experimental and control groups were given tasks on listening and speaking, similar to those given on the ascertaining stage. The difference was that they used the subjects covered in the experiment and, accordingly, lexical and syntactic samples. The analysis of the results of the testing showed that all the components of oral speech among the students of the Faculty of Pedagogy improved significantly: for the students of the experimental group, on average by $10-15 \%$, while the students of the control group remained practically on the same level as expected.

Table 3. The results of the control group on the control stage of the experiment

\begin{tabular}{|l|l|l|l|l|}
\hline $\begin{array}{l}\text { Language components / } \\
\text { Proficiency level (\%) }\end{array}$ & A1 & A2 & B1 & B2 \\
\hline Speech skills & 58 & 34 & 8 & \\
\hline $\begin{array}{l}\text { Understanding the topic and } \\
\text { situation of communication }\end{array}$ & 35 & 60 & 5 & \\
\hline Ability to keep the dialogue & 71 & 26 & 3 & \\
\hline Using prepared model & 14 & 72 & 14 & \\
\hline $\begin{array}{l}\text { Activation speech and extra } \\
\text { linguistic means }\end{array}$ & 22 & 64 & 14 & \\
\hline
\end{tabular}

Table 4. The results of the experimental group on the control stage of the experiment

\begin{tabular}{|l|l|l|l|l|}
\hline $\begin{array}{l}\text { Language components / } \\
\text { Proficiency level (\%) }\end{array}$ & A1 & A2 & B1 & B2 \\
\hline Speech skills & 42 & 38 & 20 & \\
\hline $\begin{array}{l}\text { Understanding the topic and } \\
\text { situation of communication }\end{array}$ & 28 & 56 & 16 & \\
\hline Ability to keep the dialogue & 38 & 45 & 17 & \\
\hline Using prepared model & 24 & 62 & 14 & \\
\hline $\begin{array}{l}\text { Activation speech and extra } \\
\text { linguistic means }\end{array}$ & 23 & 52 & 25 & \\
\hline
\end{tabular}

\section{Discussions}

In the course of the research, the following results were achieved: the use of a communicative approach in teaching English to students of non-linguistic specialties, subjects, and vocabulary of a regional orientation made it possible to significantly increase students' interest in learning a foreign language and improve their communication skills. As a result, students have skills and abilities in such types of speech activity as speaking, listening, used in the most common standard situations of social, cultural and educational spheres of communication. During the experimental work, dialogues were developed with the use of regional vocabulary, recreating typical situations of communication, which, we think, made it possible to use the

XLinguae, Volume 11 Issue 1, January 2018, ISSN 1337-8384, eISSN 2453-711X 
opportunities of the communicative approach in teaching a foreign language to students of non-linguistic specialties much more effectively.

\section{Conclusion}

In the course of the experimental study aimed at studying the positive practical experience of using didactic (lexical) material of regional content in implementing the communicative approach in teaching English to students of non-linguistic specialties, as shown by experimental data, as well as by interviews with students and questionnaires, the possibilities of using lexical material of regional content were determined, there were developed six dialogues for students on regional topics in English. The specificity of the author's methodology and techniques of using language tools allowed the teacher to improve the effectiveness of training sessions and raise the interest of students to learn English. This is reflected, in particular in, as we note, students' developing communication skills successfully. This was reflected in the fact that they managed to cope with excessive shyness, take the initiative, the role of a leader in the process of solving the project task, that is, in creating a situation of communication and writing dialogue. This also confirms the idea that a thoughtful combination of quality lexical content and the original form of its presentation (in situations, dialogues, games, dramatization, etc.) can give a significant didactic and educational effect

In addition to ensuring a positive effect of this project from the linguistic and emotional, educational positions, and also promoting the development of such personal qualities as the ability to compete, the desire for victory, the development of skills of self-presentation and advertising, leadership and organizational qualities that will undoubtedly be useful for future specialists in conditions of modern society, this study cultivates love for their "minor homeland". As it follows from the students' answers to the questions of the questionnaire, during the experimental work their interest to the history of their native Vyatka region, a sense of local patriotism, pride in the success and achievements of their countrymen, and the desire to make their native city better were awakened. The study also confirmed the need for further research in the search for new, even more, effective approaches in the field of teaching foreign languages at universities, and this task is actualized in connection with Russia's entry into the Bologna agreement in the field of education.

\section{Acknowledgement}

The work is performed according to the Russian Government Program of Competitive Growth of Kazan Federal University.

\section{Bibliographic references}

BOJOVIC, V. - PALUNOVIC, L. - TICA, L. 2015. Communication skills in engineering professions: Communicative language ability in foreign languages. In: International Journal of Engineering Education, vol. 31, n. 1, pp. 377-383. ISSN 0949149X.

BOJOVIC, Z. 2016. Teaching the children of migrants and refugees. In: Arts \& Humanities, vol. 10, n. 2, pp. 149-160. ISSN 1854- 9632.

CONVERTINO, C. 2016. Beyond Ethnic Tidbits: Toward a Critical and Dialogical Model in Multicultural Social Justice Teacher Preparation. In: International Journal of Multicultural Education, vol. 18, n. 2, pp. 125-142. ISSN 1934-5267.

GALSKOVA, N.D. - GEZ, N.M. 2006. Theory of teaching foreign languages. Linguodidactics and methodology. Moscow: Academy. ISBN 5-7695-2969-5. 
GORYNINA, A.A. - SOSNINA, N.G. 2015. Role-play as a form of activizing communicative skills of students of non-linguistic universities. Foreign languages: linguistic and methodical aspects: a collection of materials. Tver: TSU, pp. 16-21. ISSN 2306-2282.

GREENFADER, C.M. - BRAUILLETTE, L. 2013. Boosting language skills of English learners through dramatisation and movement. In: Reading Teacher, vol. 67, n. 3, pp. 171-180. ISSN 00340561.

IRISKHANOVA K.M. 2003. European competencies in foreign language proficiency: study, training, evaluation. Moscow-Strasbourg: Council of Europe, Department of Language Policy, Moscow State Linguistic University. http: // www.linguanet.ru

KASIMOVA, L.A. 2009. Content and the technology of teaching foreign languages in the conditions of higher education modernization. PhD Thesis. Kazan: KSU.

KHABIROVA, S.L. - RUSLANOVA, M.L. 2015. Technology of dramatization as a creative method of teaching English as a foreign language (by an example of a special course «English Theatre». In: Mediterranean Journal of Social Sciences, vol. 6, n. 3, pp. 296-300. ISSN 20392117.

MAHERZI, S. 2011. Perceptions of classroom climate and motivation to study English in Saudi Arabia: Developing a questionnaire to measure perceptions and motivation. In: Electronic Journal of Research in Educational Psychology, vol. 9, n. 2, pp. 765-798. ISSN 1205361.

MARCELIO-BARES, G. - LIURDA, E. 2013. Interactionalization of business English communication at university: a three-fold needs analysis. In: Iberica, n. 26, pp. 151-169. ISSN 23402784.

MARTYNOVA, I.N. - SHUGAYEVA, N.Y. - KORMILINA, N.V. NIKITINSKAYA, L.V. - GROMOVA, Y.N. - VASSILYEVA, Y.N. 2015. Modern approaches to teaching English lexicography at the University of Freiburg, Germany. In: Mediterranean Journal of Social Science, vol. 8, n. 3, pp. 220-226. ISSN 20399340 .

MIKHAYLENKO, T.M. 2011. Games technology as a form of educational technologies Pedagogy: tradition and innovation: Proceedings of the international scientific conference Tchelyabinsk, pp. 140-146. ISBN 978-5-903618$52-1$.

MILRUD, R.P. - MAKSIMOVA, I.R. 2000. Modern conceptual principles of communicative teaching foreign languages. In: Foreign Languages at School, n. 4, pp. 37-46. ISSN 0130-6073.

MIROLYUBOV, A.A. 2010. Methods of teaching foreign languages: traditions and modernity. Obninsk: Title. ISBN 978-5-86866-5245-0.

NAZAROVA, M.S. - GALIULLINA, E.N. 2016. Game-based learning in teaching English. In: Journal of Organizational Culture, Communications \& Conflict, n. 20 (Special Issue), pp. 8-12. ISSN 15440508.

NKWETISAMA, C.M. 2013. Literature and TEFL: Towards the reintroduction of literatures in English in the francophone secondary school curriculum in Cameroon. In: International Journal of Applied Linguistics and English Literature, vol. 2, n. 6, pp. 169-179. ISSN 22003592.

PALMER, G. 1960. Oral method of teaching foreign languages. Moscow: Uchpedgiz.

XLinguae, Volume 11 Issue 1, January 2018, ISSN 1337-8384, eISSN 2453-711X 
PASSOV, E.I. 1989. Fundamentals of the communicative methodology for teaching foreign-language communication. Moscow: Russian language. ISBN 5-200-00717-8.

PASSOV, E.I. 1991. Communicative method of teaching foreign speaking. Moscow: Education. ISBN 5-09-000707-1.

PAVLOVSKAYA, I.Y. - BASHMAKOVA, N.I. 2007. Methodological fundamentals of teaching foreign languages. St. Petersburg: St. Petersburg State University. ISBN 978-5-8465-0663-3.

POMELOVA, E.V. 2009. On some methods of teaching foreign languages in a modern university. Russia of the XXI century: regional youth policy. Kirov: VSHU, pp. 96-101. ISBN 978-5-933825-773-3.

POMELOVA, E.V. 2010. Forming communicative skills of future primary school teachers in English. Development of the child as a result of educational activities in preschool and primary school. Kirov: VyatGGU, pp. 278-282. ISBN 978-5-93825819-8.

POMELOVA, E.V. 2010. Language thematic and lexical fields. Actual problems of publishing and editing. Kirov: VSHU, pp. 147-152. ISBN 978-5-93825-813-6.

PONOMARENKO, L.N. - ZLOBINA, I.S. - GALITSKIH, E.O. - RUBLYOVA, O.S. 2017. Formation of the foreign language discursive competence of pedagogical faculties' students in the process of intercultural dialogue. In: European Journal of Contemporary Education, vol. 6, n. 1, pp. 89-99. ISSN 2304-9650.

RODRIQUEZ, L.F.G. 2015. Critical Intercultural Learning through topics of deep culture in an EFL classroom. Ikala, vol. 20, n. 1, pp. 43-59. ISSN 01233432.

SAFONOVA, V.V. 1996. Studying languages of international communication in the context of the dialogue between culture and civilization. Voronezh: Istoki. ISBN 588242-033-4.

SHAMOV, A.N. 2008. Methods of teaching foreign languages: General course. Moscow: Science.

SOMSAI, S. - INTERAPRASERT, C. 2011. Strategies for coping with face-to-face oral communication problems by Thai University students majoring in English. In: GEMA Online Journal of Language Studies, vol. 11, n. 3, pp. 83-96. ISSN 1675-8021.

SUMTSOVA, O.V. - AZHEL, Y.P. - BUYANKINA, A.S. 2016. Web quest-based role play as a way of raising students' motivation to studying foreign languages. In: International Journal of Emerging Technologies in Learning, vol. 11, n. 3, pp. 63-66. ISSN 18630383.

SYSOEV, P.I. 2013. Information and communication technologies in linguistic education. Moscow: Librocom. ISBN 978-5-397-03791-4.

VALEEV, V.A. - VALEEVA, L.A. - SIRAZEEVA, A.F. 2015. Study of University students foreign language speech activity formation. In: Review of European Studies, vol. 7, n. 5, pp. 38-46. ISSN 1918-7173.

ZALUTSKAYA, S.Y. - OSHCHEPKOVA, A.I. - NIKONOVA, N.I. 2017. Practice of teaching cross-cultural communication to humanities master students: regional specifics. In: Man in India, vol. 97, n. 6, pp. 109-122. ISSN 00251569.

Words: 8146

Characters: 53667 (29,81 standard pages)

Prof. Vladimir B. Pomelov, Dr. of Education 
Department of Pedagogy

Vyatka State University

36 Moscovskaya Str.

610002, Kirov

Russia

vladimirpomelov@mail.ru

Assoc. Prof. Rezeda R. Khairutdinova, PhD in Philology Institute of Psychology and Education

Kazan (Volga region) Federal University

18 Kremlyovskaya Str.

420008 Kazan

Russia

rezeda_raf@mail.ru

Prof. Nina I. Kryukova, Dr. of Law,

Department of State-Legal and Criminal Law Disciplines

Plekhanov Russian University of Economics

Moscow, Russia

36 Stremyannyi Pereulok Str.

115093 Moscow

Russia

ninari68@mail.ru 